\title{
Zemlinsky's The Chalk Circle: Artifice, Fairy-tale and Humanity
}

\author{
ROBERT BLACKBURN
}

Ich bin friedlos, ich bin durstig nach fernen Dingen. (I am restless.

I am athirst for faraway things.)

Tagore, Der Gärtner / Zemlinsky, Lyric Symphony

The life and work of the Austrian composer Alexander Zemlinsky (1871-1942) is better known than it used to be thanks to the passage of time, and the availability now of almost all his music on record. During his lifetime he became used to neglect and under-valuation, except from his most intimate circle. Arnold Schoenberg was his lifelong friend and brother in law, and it was Schoenberg, who, even during the years when his "reluctant revolution" of twentieth century modernism in music was attracting so much attention, never for a moment lost his admiration for and loyalty towards Alex, his much-loved teacher and colleague through so many trials.

Now that the correspondence between them has been published ${ }^{1}$ we can see the extent and detail of their relationship, their intense and consistent lifelong devotion, despite some disagreements. On Zemlinsky's side we are aware always that he felt Schoenberg was the greater genius, a unique pioneering figure. In the letters, he is always "lieber Schoenberg"

1. Alexander Zemlinsky (ed. and enlarged by Horst Weber), Briefwechsel mit Schoenberg, Webern, Berg und Schreker, Darmstadt Wissenschaftliche Buchhandlung, 1995. 
never Arnold. For Schoenberg, who always addressed him as "lieber Alex," Zemlinsky was someone he could, beyond all others, rely on for succour and support. It may have been Franz Schreker who conducted the first performance of Gurrelieder in Vienna in 1913 (Schreker was the founder/conductor of the Vienna Philharmonic Choir, which he had started in 1909) and was also a lifelong friend of Schoenberg, though more so in later years (after 1920). But it was Zemlinsky who in 1924, fifteen years after its composition, conducted the first public performance of Erwartung of 1909 a key masterpiece of Expressionist music. The companion theatre piece, the highly personal Die glïckliche Hand was conducted in Vienna by Fritz Stiedry in October 1924. Today, these have long been recognised as pivotal works in the history of modernism. Zemlinsky knew at the time, instinctively, how important they were, and would be seen to be by posterity. Beyond question, Zemlinsky was a great interpreter of older music, and inheritor of Mahler's tradition, who early established a career-path as a composer-conductor. This led him to the Volksoper (1906-1911) in Vienna and briefly (1907-1908) to the Hofoper. After 1911, he settled in Prague, remaining there until 1927 at the best of the German-speaking musical community there. It was Stravinsky who declared that the Le Nozze di Figaro he saw and heard under Zemlinsky's baton in Prague was the finest he ever experienced. Before that, Mahler himself had recognised his talent, and had done much to encourage him.

Schoenberg's pupil Egon Wellesz (1885-1974), an exact contemporary of Alban Berg, remembered Zemlinsky as:

Only about two years older (than Schoenberg)...(he was) around this time (1910) a rising composer...He was a musician of unusual depth and technical mastery, much admired by Brahms. Despite his ugliness, he emanated remarkable charisma. He was a brilliant talker, if also (rather) cynical: for like many gifted Austrian musicians, he had spent the best part of his youth in provincial theatres, largely conducting operettas ${ }^{2}$.

A Zemlinsky pupil, Josef Wenzl, writing in the early 1920s, called him a bundle of nerves, though the tone is undoubtedly one of admiration:

2. Egon and Emmy Wellesz, ed Franz Endler, Egon Wellesz: Leben und Werk, Vienna and Hamburg, Paul Zsolnay Verlag, 1981, p. 36. 
The little man is so nervously and agitatedly active, filled with sparkling vitality, both in life generally and on the rostrum. Zemlinsky the composer is so rich in spirit (geistreich) so intoxicated with modern aesthetics, sarcastic, aggressive, and forever clinging to the idea of "beauty" in his works ${ }^{3}$.

This study is primarily concerned with the background to Der Kreidekreis, Zemlinsky's setting of a Chinese drama by Alfred Henschke (pen name 'Klabund', 1890-1928). This was the last of Zemlinsky's stage works to be performed during his lifetime. Indeed, it was the last to be performed anywhere (apart from a solitary production at Nuremberg in 1955) until the slow revival of interest in his music. In terms of scholarship, Horst Weber's monograph, published in $1977^{4}$, was the first landmark in this process, as well as the first-ever biography and academic study of Zemlinsky in any language. Unlike Schreker, who benefited from three biographies by the time he was 43 , Zemlinsky was given only a special issue of the Prague music journal Auftakt for his fiftieth birthday in 1921. A year later the Universal Edition house journal Ausbruch published three short tributes to Zemlinsky as composer (by Franz Werfel) as conductor (by Heinrich Jalowetz) and as teacher (by Erich Korngeld) - certainly a distinguished trio 5 . But the general accounts of contemporary music of the time, such as those by Rudolf Louis, Oscar Bie, H. J. Moser and Adolf Weissmann either refer fleetingly to Zemlinsky or ignore him altogether.

The fact that Zemlinsky did complete another full-length opera, König Kandaules (after André Gide's Le Roi Candaule, in Franz Blei's translation) in short score, and made considerable progress with yet another project on another classical subject, Circe, adds to the remarkable story of oblivion and gradual recovery. For if Circe must always, necessarily, remain a fragment, König Kandaules has actually been rescued, restored and orchestrated by the conductor-scholar Anthony Beaumont and performed. The work is now a fascinating part of the substantial Zemlinsky's music, alongside Gerd Albrecht, Lothar Zagrosek, Stephan Soltesz and others, and has now (1999) recorded all of

3. Josef L. Wenzl, "Deutsch-Österreichische Kunstlerbilder", Neue Musikzeitung 44/2, 1923, p. 24.

4. Horst Weber, Alexander Zemlinsky, Vienna, Elisabeth Lafite, 1977.

5. Anbruch 4 Jg., 1922, pp. 74-79. 
Zemlinsky's choral music, including his moderately well-known setting of the Twenty-third Psalm.

No-one would have enjoyed the irony of this new awareness and appreciation of Alexander Zemlinsky the composer more than the man himself, with his general tendency to rueful, somewhat sardonic selfdeprecation. Unlike Schreker, he sought fame and valuation primarily as an opera composer, belonging to the last two generations in Europe (born between 1870 and 1890) to do so. In fact he produced three undoubted masterpieces in other forms which he must have known even at the time were exceptional works. Others in his circle were keenly aware of their quality and significance. These were the Six Maeterlinck Songs of 13 of 1910 , settings of quiet distinction and serene beauty, to profound, energetic and searching Second String Quartet of 15 of 1915, and the Lyric Symphony for baritone, soprano and orchestra of 1922, settings of poems by the great Bengali poet Rabindranath Tagore, from his collection The Gardener (Der Gärtner).

The Lyric Symphony has become his main standard-bearer in our time, deservedly his most recorded and publicly-performed piece, a deeply serious, coherent and powerful late-Romantic expression of Sehnsucht, of that yearning for beauty and fulfilment which lay at the heart of his work. Though the Lyric Symphony is partly modelled on Mahler's Das Lied von der Erde, the feeling and sound of Zemlinsky's song-symphony are actually very different from Das Lied, as a comparison of the two quickly shows. The Lyric Symphony now seems to be, with Der Zwerg, written alongside it, a work towards which Zemlinsky was moving for many years from his innermost being and experience. Impersonal (through Tagore's poems) yet at the same time highly personal, it has always stood on its own merits, and is not merely an accidental beneficiary of the enormous popularity of Mahler's music since the 1960s.

Theodor Adorno's well-known essay of 1959 on Zemlinsky (written with a companion-piece on Schreker) ${ }^{6}$ is packed with first-hand detail of many of his works Adorno observed that:

Cultural products can only justify themselves nowadays by their immediate relevance and by their ability to speak directly. In such circumstances, Zemlinsky would have

6. Quasi und Fantasia, Frankfurt, Suhrkamp, 1963, pp. 155-180. 
nothing to say to use if his achievements were purely historical. We would be merely left with the pointless memories of a man who, just a few years after his death, had fallen into such total oblivion that even the discovery of the simplest data and getting hold of the scores of his works are fraught with the greatest difficulties ${ }^{7}$.

Essentially, Adorno saw Zemlinsky as a warm and sensitive eclectic, unfairly and unjustly marginalised, whose time might eventually come. Schoenberg himself predicted just that. Full of praise for the Gottfried Keller opera Kleider machen Leute (first version 1910, second, revised and shortened version 1921-1922) he notes especially Zemlinsky's strong sense of form, and his humanity. Der Kreidekreis is seized on as a model of Zemlinsky's later manner. It is clear from his remarks that Adorno had seen the Berlin production of early 1934, by Franz Ludwig Hörth, conducted by Robert Heger; quickly removed from the Theater am Platz der Republik by the Nazis. Adorno also links Zemlinsky's manner in Der Kreidekreis to the Weill-Brecht Dreigroschenoper, rather than to Aufstieg und Fall der Stadt Mahogany, which Zemlinsky had conducted at the soon to be closed Krolloper in Berlin in 1930. Finally, Adorno also saw Zemlinsky's "cultivation" and "lack of ruthlessness" as the root of his final obscurity.

Today it would be difficult to return with comfort to the vision of the orient available to the young Zemlinsky, let alone to those present when, approaching the age of sixty, he set Klabund's play as an opera. Edward Said's 1978 study Orientalism ${ }^{8}$ with its deliberately political argument, sets out the western idea of Orientalism as a "corporate institution', which exists for and by making statements about the east, authorising views of it, describing it, teaching it, settling it, ruling over it...' Said saw Orientalism challengingly as a concept aimed at having authority over the Orient.' There are, he says, indications always of the Western tendency to exploit oriental stereotypes of deportation, splen-

7. Tr. Rodney Livingstone, in Quasi und Fantasia, Verso, 1993, p. 120.

8. Edward W. Said, Orientalism, London and New York, Routledge and Kegan Paul, 1978. 
dour, cruelty, sensuality...promise, terror, sublimity, idyllic pleasure, intense energy ${ }^{9}$. While an ostensible Near Eastern exoticism in Verdi's Aida has been interpreted recently as essentially looking back to the Risorgimento rather than forwards to the new later $19^{\text {th }}$ Century politics ${ }^{10}$. With respect to the domination of nineteenth century Russian opera by the orientalist strain, Richard Taruskin has commented on the way, for Russian composers "the Eastward gaze is simultaneously a look in the mirror"11. This was with reference to his general view that Tchaikovsky, alone among Russian composers of his time, seemed relatively immune to the lure of the east.

Zemlinsky began his career as an opera composer with an apprentice work obliquely in that Russian tradition, Sarema. He ended it, effectively, in the 1930s with König Kandaules, after Gide's Le Roi Candaule, even though this work was never fully scored, let alone performed. Temperamentally, he was driven to pre-existing literary sources as material for his texts. He would never have followed Schreker's path of becoming his own librettist. The operas he actually wrote reveal a strong interest in narrative themes contrasting anecdotal and dramatic effectiveness with a highly-coloured or unashamedly exotic setting on the one hand, and on the other a link with the older style of fairy-tale (Märchen) or folkopera. He was, after all, music director of the Vienna Volksoper from 1906 to 1911 when he left to take charge of the German opera house in Prague, remaining there for sixteen productive years.

Because Zemlinsky's career as a conductor took preference, like Mahler's, the fact that he was a "summer" composer in general limited his oeuvre. His works are characterised by a fastidious craftsmanship (recognised by everyone) and by an unwillingness to attempt the grandiose, the heroic or the extremer forms of the mystical. Sarema, for which Schoenberg prepared the vocal score in 1897, was based on Rudolf von Gottschall's play Die Rose vom Kaukasus. This is a rather confused

9. Edward W. Said, Orientalism, Chapter 4, pp. 119-120, Quoted in Ralph P. Locke: 'Constructing the Oriental Other' Saint-Saëns Samson et Delila. Cambridge Opera Journal, vol. 3, n 3, 1992, pp. 263-264.

10. Paul Robinson, "Is Aida an Orientalist Opera?", Cambridge Opera Journal, vol. 5, n², 1994, pp. 133-140.

11. Richard Taruskin, "Russian Musical Orientalism; a Postscript", Cambridge Opera Journal, vol. 1, n 6, 1989-1990, p. 84. 
romantic melodrama, concerned with the tension between Czarist Russia and the remote Caucasus, symbolised in Sarema, her father Amul Beg, and the young, defiant Caucasian leader Asslan, himself in love with Sarema. The colourful second act with its wild moonlit mountain scene, filled with emotional and warlike Caucasians, among whom Sarema herself appears dramatically probably reveals why Zemlinsky was attracted to it. It is a conservatively-written foreign by-product of the school which produced The Maid of Pskov and Prince Igor. Sarema's interest for us lies in its long-size relationship with Der Kreidekreis. In both works one sees Zemlinsky the instinctively homophobic composer (as against Schoenberg the polyphonist) as well as a composer who, in general, avoided large Straussian gestures, seeking his effects in smallerscale ways. Though Haitang's final romantic apotheosis in Der Kreidekreis is at some distance from the Caucasian Girl's spectacular suicide, Haitang is in one sense a tragic heroine like Sarema. Certainly none of the female roles in between equal these two in dramatic scope.

Mahler conducted Es war einmal, Zemlinsky's second opera in Vienna in 1900 but Der Traumgörge, the most original of the early stage works (based on text by Leo Feld after Holger Drachmann) was never performed in the composer's lifetime; it had to wait until 1983. Kleider machen Leute, a comic opera, is commonly felt to be one of the best, if not the best, of Zemlinsky's operas, well characterised, humane and richly-scored. His instinct told him so, since he took it to Prague with him and revised it for performance in 1922. This was the period of Zemlinsky's immersion in Wilde, producing A Florentine Tragedy, based on the incomplete posthumous dramatic fragment, as well as Zemlinsky's most personal stage-piece, the one-act Der Zwerg (The Dwarf). This was a setting of the widely-known story The Birthday of the Infanta from the collection The House of Pomegranates. The place of this story in German music from 1908 to 1918, particular through Schreker, has been much discussed in recent years.

Der Zwerg was the tragedy of an ugly man - as was Schreker's Die Gezeichneten. It was known by all who knew Zemlinsky at all to be on one level and intimate realisation of his own self-image and selfperception, one which he seemed to encourage in others. By no stretch of the imagination could Zemlinsky be called good-looking, and his features tool on an even more crabbed look as he aged. However, a 
photograph of him, Schoenberg and Schreker taken together in Vienna in 1912, reveals a man of forty who was equally far from being "ugly" in any obvious or conventional sense. The point is that the legend of Zemlinsky's physical "ugliness" entered the public domain, permanently, through the comments and memoirs of others. Behind the setting of Der Zwerg lay the long-buried trauma of Zemlinsky's affair with Alma Mahler in 1898-1901, her rejection of him, and her marriage to Mahler in 1902. Alma's recently published Diaries 1898-1902 reveal the extent of her elaborate and coquettish involvement with her teacher and friend at that time $^{12}$. Yet despite this pain, Zemlinsky kept up a friendship with her to the end of his life.

This period spanning the immediate past -1918 years was the most productive of Zemlinsky's career. The tragic beauty of the Der Zwerg score coincides in time with the brilliance and simultaneous energy and inwardness of the Tagore Lyric Symphony. Zemlinsky's "yearning" figure:

\section{Example 1}

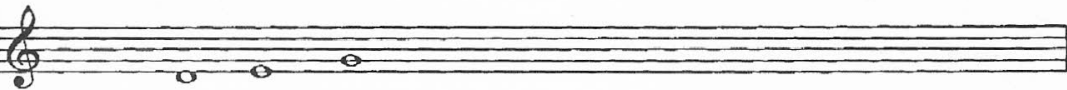

Is an unconscious feature of several works from the Maeterlinck songs onwards and forms the opening figure of the Second String Quartet ${ }^{13}$. It is a partial echo of the opening of Mahler's Ninth Symphony:

Example 2

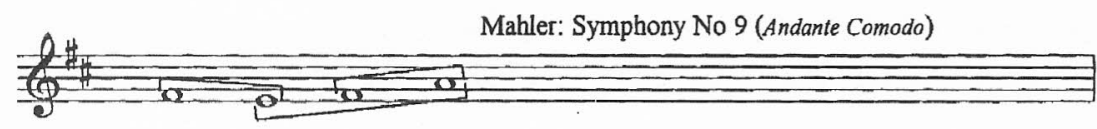

12. Alma Mahler Werfel, tr. and ed., “Anthony Beaumont", Diaries 1898-1902, London Faber, 1998.

13. Anthony Beaumont, "Schicksalsakkord und Lebensmotor", Hartmut Krone (ed.), Alexander Zemlinsky Ästhetik, Stil,Umkreis, Wien und Leipzig, Bohlen Vlg, 1995. 
The position of Tagore in Europe around 1920, following his 1913 Nobel Prize for literature, has been many times discussed. He visited Prague amongst other European capitals, and Zemlinsky may well have heard him speak in public. Janácek certainly did, commenting remarkably that 'We couldn't understand the sense of what he said but the melody of his soul's bitter suffering was unmistakable"14. Tagore was as instinctively suitable a choice for Zemlinsky as Bethge's Die Chinesische Flöte had been for Mahler in 1906-1907. This was despite the widespread misinformation about Tagore, which prevailed at the time and was at the heart of the popular adulation of the Bengali poet. Few seemed to realise that the German versions of his poems, by Hans Effenberger, were actually translations from the English versions (by Tagore himself) published by Macmillan, and were therefore still further removed from the Bengali original.

Further, there was, beyond the popular naïve admiration, a resentment by some of what was seen as Tagore's "pose" and the weakening influence of his apparent mildness and passivity. One journal in Berlin in 1921, for example, rejected Tagore as a 'nebulous' ecstatic', while a Viennese journalist contrasted Tagore's idealism with the bitter harshness for so many of everyday life in post-war Austria ${ }^{15}$. Some Austrians had not forgiven Tagore for being preferred as Nobel Prize-winner to the Austrian peasant poet Peter Rosegger.

None of this can have affected Zemlinsky, whose choice of the seven poems from The Gardener, in his own words, projected an inner sense of their belonging together (Zusammengehörigkeit), a "Grundton" (underlying unity) and sequence described by one critic as 'Sehnsucht, Erwartung, Erfüllung, Befreiung, Abschied' (Longing, Expectation, Fulfilment, Liberation, Farewell ${ }^{16}$. Zemlinsky said that the whole mood of the Lyric Symphony sprang from the Vorspiel and the first song, and that whatever differences there were between the other six were outweighed by the 'relationship back' to the beginning.'

14. Leós Janácek, Musik des Lebens: Skizzen, Feuilletons, Studien, Leipzig, ed T. Strakova, 1979, p. 131.

15. Martin Kämpchen: Rabindranath Tagore and Germany: A Documentation, Calcutta, Max Mueller Blavon, Goethe Institut, 1991, p. 15 f.

16. Rudolf Stephan in Vom musikalischen Denken. Gesammelte Vorträge, A. Mainz,ed. Damm, R. and Traub, 1985, p. 30. 
Life experience, not memory or recollection is at the root of the Lyric Symphony, for which the composer wanted a "Heldenbariton" (heroic baritone) and a young dramatic soprano as his two protagonists, who are partners, or lovers. This alone distinguishes the Lyric Symphony from his Das Lied von der Erde, where the voices (tenor and alto/ baritone) are separated by pitch rather than by gender as such ${ }^{17}$.

After the peak of prominence in 1920-1923, Zemlinsky's composing activity tailed off markedly. The Sinfonische Gesänge of 20 , six songs based on translated poems by black American poets (including Langston Hughes) in a 1929 collection published in Vienna, were performed only in 1933, also in Vienna, but not actually published by Universal Edition at the time ${ }^{18}$. Then came Der Kreidekreis on which the composer worked steadily for two years from 1930. The opera in three sets (seven scenes) was based on Klabund's play, which had been a big success on its appearance in 1925, directed as it was by Max Reinhardt and starring Elizabeth Bergner as Haitang. The whole style of Zemlinsky's new opera completed by the autumn of 1932, and first given at Zürich on 14 October 1933, seemed to have links with composers a generation younger than himself. There were many touches about the harmonies and voice-leading which were reminiscent of Hindesmith (who was working on his new opera, Mathis der Maler at that time). Zemlinsky could certainly have known Hindesmiths's Hoffmann opera Cardillac. Then there was the jazz/ topical flavour of the young Ernst Krenek's Jonny spielt auf! - the major popular operatic success of 1927 in Germany. The spoken dialogue in this work leads one to the same technique in Kurt Weill, to whose music Zemlinsky was clearly drawn, despite Schoenberg's declared hostility to the Weill idiom.

17. Monika Lichtenfeld, Zemlinsky und Mahler, in Otto Kolleritsch (ed.), Alexander Zemlinsky: Tradition im Umkreis der Wiener Schule, Universal Edition, Graz, 1976, pp. 101-110.

18. Anna Nussbaum (ed.), Afrika singt! Eine Auslese neuer afro-amerikanischer Lyrik, Wien, F. G. Speidelsce Verlagsbuchhandlung, 1929. 
For Brecht and Weill, the theatrical drive was, of course, heavily didactic and political. It is unlikely that, by temperament, Zemlinsky could ever have followed them far down their particular road, though he would probably have enjoyed Der Silbersee (1933), Weill's last work to be given in Germany a collaboration with Georg Kaiser. Brecht's and Weill's 'eastern' inspiration was in any case the Japanese Noh-play, as in the adaptation of Taniko into Der Jasager or the YeaSayer. But years later, Brecht typically used Der Kreidekreis himself, for his own objectives, in Der kaukasische Kreidekreis, creating one of his best-known plays. Klabund had taken this Yuan (Mongol) dynasty Chinese 'Sittendrama', or morality play, from the well-known French translation by Stanislav Julien, L'histoire du cercle de craie. Hoei-lan-ke, the drama of the chalk circle, has by the otherwise anonymous writer/civil servant Li-Hsing-tao, and had already been translated into German ${ }^{19}$. Klabund saw the opportunity to rework this material in his own way, and took it gladly.

Alfred Henschke was born at Crossen an der Oder on the Silesia/ Brandenburg border in 1890, the same year as Werfel, and died early of tuberculosis in 1928 in Davos sanatorium. Henschke became a member of Alfred Kerr's influential "Pan" circle. He saw the Munich "Japan und Ostasien in der Kunst" exhibition of 1909, and in 1919 published a volume of poems (written in 1908-1913) entitled Die Geisha O-Sen on an 18th century Japanese courtesan. The interest of the "Fernost Rilke" (Far-eastern Rilke) as he was later mockingly described, was thus already aroused when in 1915 he read Bethge's Li-tai-pe translations. Through these he became acquainted with Laotse and with 2 wide range of oriental literature in translation. Klabund did not wish to imitate Bethge, but to realise what he called the "sehr unruhig, oft skurril' (very disturbed, often scandalous) echoes and associations of the original, whose apparent simplicity arose, he said from the fact that Chinese

nur einsilbige Worte kennt, und ihr gleiches Nebeneinander eintönig scheint. Aber nur scheint. Die Chinesische Gedichte sind unerhört kompromiert. (Only knows single

19. By Wolheim da Fonseca, Reclam, Leipzig, 1876. 
syllable words, and seems, side by side, monotonous. But only seems. Chinese poetry is extraordinarily compressed.) $)^{\mathbf{2 0}}$.

Several volumes of verse translation followed, so that when, in 1923, the Schauspieltheater gave Klabund the commission which resulted in Der Kreidekreis, he was already a well-known figure. The play was first given at Meissen Stadttheater on 1 January 1925, and two days later simultaneously in Hannover and Frankfurt. Herbert Jhering did not care for it, saying that the play's effect lay in bourgeois overflowing of emotion and in the special exotic atmosphere ${ }^{21}$. Nevertheless, the play ran for over a hundred performances at the Deutsches Theater, Berlin.

Zemlinsky almost certainly never met the slowly dying poet, but in the light of his feeling for Maeterlinck, Dehmel, Wilde and later Tagore, it is easy to see why he liked Klabund's play. The new translation though based on Julien's translation of the original Chinese was altered by Klabund in both style and content. This was aimed at simplifying the action, and bringing out the theme of justice and social comment. Louise Zemlinsky (1990-1992) his second wife, started the libretto for Zemlinsky, who then composed it steadily for 3 July 1930 in Prague, finishing the work in Berlin on 8 October 1932, and very properly dedicated it to Louise. Paul Stephan (editor of Anbruch) gave a talk before the first performance in Zürich (conducted by Robert Kolisko) outlining Zemlinsky's distinguished career. Reviews were good, and one critic commented on the platform constructed into the orchestra pit to allow the singers to introduce themselves in the traditional Chinese manner. For German theatres it took up (Stettin, Coburg, Nuremberg, Berlin) as well as Prague, Graz and Bratislava. But censorship and Nazi activism ensured the end of the work on German stages before the summer of 1934.

Writing in 1922, a commentator had observed of Chinese theatre that it was a sort of animated dance of diverse sentiments accompanied by songs and dialogues, acted to musical sounds ${ }^{22}$. As early as Goethe in

20. Klabund, letter to Insel Verlag, May 1915, quoted in Guido von Kaulla: Brennendes Herz Klabund: Legende und Wirklichkeit, Zürich und Stuttgart, W. Classen Verlag, 1971, p. 78.

21. Herbert Jhering, Von Reinhardt bis Brecht 2, pp. 79-81.

22. Tchon-kia-kien, Le théâtre chinois, Paris, M. de Brunoff, 1922, p. 30. 
1827, European writers were observing Chinese life to be clearer, purer and more moral, and Chinese legends to revolve mainly round "morality and propriety"23. But German histories of the Chinese theatre did not try to disguise the problems of the oriental stage-conception, in particular the stress on the song-form and the flatness of the dialogue. It was argued that the Chinese drama, for all its sad situations, lacked true tragic quality. Gottschall even spoke of the comparative aridity of Chinese drama: its magnificent costumes and tapestry backcloth were the sole concession to luxury, stage proprieties (usually symbolic) being largely rudimentary.

Der Kreidekreis belongs to the type of play criticised for lack of real intellectual dimension, simplistic morality (rewarding good and punishing evil) and executive use of coincidence. Grube called at the 'archetype of bourgeois theatre' ${ }^{24}$. The play's theme of false accusation, corruption, betrayal and the eventual vindication of innocence is common to several Jüan dynasty dramas. In the Sufferings of Ton- $E$, for instance, a young girl is accused of poisoning, and tortured into confession; her innocence is proved by a three-year drought, summer snow and blood falling upwards. Ho Lang Tan (The Singing Girl) presents a rich merchant, a jealous first wife who died of anger, a concubine and her lover, who are ultimately condemned to death by the first wife's son, now a judge.

The original four-act Hoei-lan-ke concerns Haitang, a prostitute whom the mandarin $\mathrm{Ma}$ wishes to marry, her five year old son, Ma's first wife Yu-Pëi and her lover Tschao, Ma's greedy brother-in-law Tschang-ling, and the plan of Mrs Ma, successfully accomplished, of poisoning her husband and blaming Haitang. All this is contained in Act 1. The eunuch Tong (at the outset) and the Emperor (towards the close) were Klabund's own inventions, while the Act 2 trial embroiders the Judge's role and conflates the two midwives into one, but otherwise adheres to the original. Klabund's single Snowstorm Landscape scene (his Act 4) with Haitang and the four soldiers, derives from the original Act 3 in which Tschao and Mrs Ma are forestalled by Tschang-ling in their attempt to murder Haitang. Finally, the court of the Emperor replaces the original higher court, following whose judgement Tschang-ling carved out the execution of Tschao and Mrs Ma at least one commentator has

23. J. W. von Goethe, Conversations with Eckermann, 31.10.1827.

24. Wilhelm Grube, Geschichte der chinesischen Literatur, Leipzig, 1909, p. 379. 
criticised Klabund for the "romantic" or "fairy-tale" ending, suggesting that a Chinese audience, welcoming Haitang's vindication, would have been offended by her remarriage ${ }^{25}$. In one sense Klabund had jettisoned the most truly Chinese element of the final act, the satire and burlesque character study of the judge and his clerk, derived from close observation, transferring this to the Hauptrichter Tschu-tschu in Act 3.

\section{4}

Zemlinsky rearranged Klabund's original five acts as follows, in seven scenes:

PLAY

Act 1 (Teahouse interior)

Act 1 (Another part of the house) scene

Act 2 (Garden and Veranda of Ma's house)

Act 2 (At room in Ma's house)

Act 3 (Courtroom of Hauptrichter in Tschen-Kong) scene

Act 4 (Snow Storm Landscape) scene

Act 5 (Throne Room in Peking)
OPERA

Act 1 , First scene

Act 1 Second

Act 2 Third scene

Act 2 Fourth scene

Act 3 Fifth

Entr'acte Sixth

Act 3 Seventh scene

The content sequence in the opera is thus:

\section{Act 1 First scene (Teahouse/Brothel interior)}

The brothel keeper Tong introduces himself. Frau Tschang and her daughter Haitang enter. They are mourning for Haitang's father, who has hanged himself in front of the house of $\mathrm{Ma}$, having been reduced by him to destitution. Frau Ma (Yu-Pei) hears the courtesans' music. She is here to sell Haitang to Tong. A price is agreed, but Haitang's brother

25. Frances Hume (tr.), The Story of the Circle of Chalk, London, Rodale Press, 1954, Intro. 
Tschang-ling rushes in to express violent disapproval. He strikes Haitang, but Tong still leads her away to an empty cage.

\section{Act 1 Second scene}

In another room in the Teahouse, Pao has met Haitang over a game of chess. He suggests they proceed to the game of love. She draws a chalk circle on the partition. Pao says that this is 'the symbol of the firmament...the ring binding together husband and wife, joining one hear to another.' 'Whatever lies outside the ring,' says Haitang, 'is nothing. Inside is the universe.' Grotesquely, Ma thrusts his head through the circle. He is a corrupt judge and tax collector. He discovers that Haitang is a virgin and bids for her. Unfortunately Pao is outbid and goes.

\section{Act 2 Third scene}

The garden of Ma's house, a year later. Haitang has borne Ma a son. Yü-Pei, who is barren, is furious. Yü-Pei is seen with her lover Tschao, telling him of her dream in which he stabs himself for her, and she drinks his blood. Tschao gives her a phial of poison. Ma tells Tschao that he wishes to divorce Yü-Pei and elevate Haitang to the rank of first wife. Tschang-ling comes in as a wandering beggar, and is recognised by Haitang. He is dismayed to hear about her son. Haitang consults the oracle of the chalk circle about whether Ma should die. The answer is unclear, as the knife rests on the circle's circumference. Haitang gives her brother her fur coat.

\section{Act 2 Fourth scene}

A room in Ma's house. Haitang has forgotten to put sugar in Ma's tea. Yü-Pei, having heard from Tschao about Ma's divorce plans, poisons the tea when Haitang is out of the room. Haitang innocently gives $\mathrm{Ma}$ the poisoned tea telling him that she has begun to love him. He drinks and falls dead. The police arrive, and Yü-Pei accuses Haitang of murder. She also claims that the child, $\mathrm{Li}$, belongs to her.

\section{Act 3 Fifth scene}

A local court. Tschu-Tschu, the magistrate, has spent the evening in Tong's brothel. Yü-Pei bribes him, the midwife and two coolies. The 
court opens. Yü-Pei accuses Haitang of trying to steal the child. The evidence is not countered, and Tschu-Tschu condemns Haitang to death. But a messenger from Peking arrives to say that the Emperor is dead. His successor has suspended all death-sentences. Judges and accused must all go to Peking. Tschang-ling is sceptical, but is arrested anyway and taken to Peking.

\section{Entr'acte Sixth scene Snow storm landscape}

This is set on the road to Peking. Haitang appears with her escort of soldiers. They are joined by Tschang-ling and the soldiers who guard him.

\section{Act 3 Seventh scene}

The Imperial throne room in Peking. The Emperor orders Tschangling's release. Haitang recognises the Emperor as Pao. Yet she refuses to answer his questions about that first Teahouse visitor. The Chalk Circle oracle reveals Haitang as the boy's mother, and Yü-Pei as Ma's killer. Tschao reveals the bribes paid to Tschu-Tschu. They are led away. The Emperor reveals that it was he who made love to her on that first night, and is her child's father. Haitang is made Empress that very day.

The composer thus laid out his text in two halves. The first two acts of Klabund's play (without scene divisions) are here divided into two, so as to encompass the establishment of the characters and the events up to Ma's death and Haitang's ascent I four scenes. Thereafter the number of excisions from Klabund increases, and Acts 3, 4, and 5 of the play are presented in abbreviated form as Scenes 5, 6 and 7 of the opera. The important trial scene is largely retained, including the whole of the idiosyncratic breakfast scene of Tschu-Tschu. This is a grotesque comic role here, entirely spoken, not sung, so as to portray the judge's frivolity. ("Gold, gold, there is no sweeter music than gold rolling over a hard table. It rings like the bells of a pagoda.") Equally, the conspiratorial role of the Hebamme (Midwife) is vital to the presentation of the Chalk Circle ritual, and is kept, as is the sinister function of the two Kulis in supporting Frau Ma's fraudulent claims. In the original Snow Storm Landscape, Tschang-ling's dramatic appearance, escorted by two soldiers, is followed by a long, bitter, emotional speech deploring the real injustice of the Chinese judicial procedure: 
O Leid! O Zeit! Wie kam ich in einem Land zur Welt, wo Gerechtigkeit nur ist für Reichen, und die Armen ein Spielball sind ihrer herrischen Lüste! In diesem Land gilt gut als böse, und böse als gut.

(O suffering! O time! How die I come into the world in such a country, where justice is only for the rich , and the poor are the plaything of their dominant whims! In this country, good stands for evil and evil for good.)

Der Kaiser aber sitzt in Peking auf seinem Thron aus Lapislazuli. Er hält die Augen geschlossen wie Gott Fo. Er sieht nur innen und meditiert.

(The Emperor sits in Peking on his Lapislazuli throne. His eyes are closed in the manner of the god Fo. He sees only inwards, and meditates. $)^{26}$.

All this was cut by Zemlinsky, who left the sole exchange:

HaITANG: Bruder! (Brother!)

Tschang-Ling: Schwesterseele! (Soul-sister!)

In the final scene, the active role of Tschang-ling is again reduced, and his position as 'Member of the Society of the White Lotus' omitted. In answer to the Kaiser's question "Du weinst: weinst Du um dein Schicksal?" (You weep: do you weep about your destiny?) Tschang-ling replies "Ich weine um China" (I weep about China.) Zemlinsky in one of his rare departures from the original text, alters this to "Ich weine um mein Vaterland" (I weep for my Fatherland) thus bringing Tschang-ling, loyal brother, even more into the foreground as a revolutionary idealist. Otherwise, Scene 7 concentrates heavily on the Kaiser-Haitang relationship, shortening the dramatically important Frau Ma-Tschao argument. This is especially true in the final section, from Haitang's "Mein Kind! Mein Panterköpfchen, Mein Luchsäuglein, mein Aprikosenänglein...." (My child! My little panther head! My little Lynx-eyed one, my little apricot pole) onwards. Her earlier long speech before the throne, beginning:

Ich halte über Euch den Stab des Rechts und brache ihn, weil ich nicht richten will.

(I hold the Staff of Justice over you and break it, because I do not want to condemn.)

is, however, omitted entirely.

26. Der Kreidekreis: Spiel in 5 Akten, Spaeth, Berlin, 1925, pp. 89-91. 
The peculiar flavour and charm of Der Kreidekreis derives from its unexpectedness in style, compared with Zemlinsky's earlier operas, coupled with an inevitability, once one considers the work in the round. It is a work of general understatement alongside moments of intense feeling. It depicts much real suffering, and yet is filled with ultimate hope and optimism. It is also tailored (the composer surely hoped) to a popular audience, yet contains those theatrical elements which appear in his earlier works - a specific scenic atmosphere and locale; a strong central female character (often, but not always a femme fatale) and a yearning for a happy, possibly domestic resolution. The style of Der Kreidekreis is a fusion of Zemlinsky's developed late Romantic chromatic, clerical style as shown supremely in Der Zwerg and the Lyric Symphony, and the new elements and tendencies which characterised German music in the later 1920s.

It would be quite wrong to accuse Zemlinsky of stylistic plagiarism of Weill and Krenek, or of Hindemith. Yet their presence and effect can nevertheless be felt. These younger composers emerged out of much the same world as he had inhabited. Fastidious and accomplished as he was, Zemlinsky was not doctrinaire. He seems to have enjoyed and understood the jazz of the 1920s, and, unlike Schoenberg, relished the new works of Kurt Weill. He was, in a word, open to new influences and popular tastes, without becoming overtly "populist" himself.

Yet he had been pre-empted in the field of "oriental" operas above all by Puccini's Turandot, already (in Alfano's completion) establishing itself with a vast audience in Europe and beyond in the very period (from 1926 to 1929) when Zemlinsky more or less fell silent as a composer. When he took up his pen once more, he had really entered a "third period" which was, through pressure, displacement, discontinuity and later on illness too, destined to be fragmentary. Der Kreidekreis was, with the Fourth String Quartet, the chief finished product of this time. Temperamentally, Zemlinsky could not have attempted to rival the brilliant fusion of Italian bel canto with rich exotic colour, oriental scales, intervals and instrumentation, let alone the great crowd scenes, used by Puccini in Turandot. Puccini's magic formula was unique to his special gifts. Zemlinsky had never written 
a "crowd" opera (compare him here with Schreker, who made this a speciality at least up to Irrelohe (1921-1923.) His finding of Klabund's text provided an ideal vehicle. Zemlinsky's response to this text was to frame the whole work in D major, his great "key of life" in its joyful and seven tragic aspects. Technically, a vital decision was to alternate melodrama, or through-composed sections, with lengthy but appropriate sections of spoken dialogue. The third aspect was the presence of a number of delicate, idiosyncratic songs, mainly for Haitang herself, to illustrate her life-journey from innocence through committing degradation towards justice and personal fulfilment.

$\mathrm{Li}$, the name of Haitang's child, is not accidental. It means "rites" or "manners", a reference to the old Chinese notion of the just regulation of human relations, "the way of the ancient kings". The struggle for the boy between Haitang and Yü-Pei, based on a lie and a crime, symbolises a wider struggle for social justice and order, with which Haitang and her brother become so strongly identified ${ }^{27}$. Irony is never far away in this story of the ultimate triumph of natural goodness against deep evil. The name of the scheming Yü-Pei (Ma's first wife) means 'jewel' and her lover and fellow-conspirator Tschao is a clerk of the judiciary.

Orchestrally, Zemlinsky writes for his standard orchestra, plus two saxophones, a jazz drum, cymbals and a banjo. The Chinese theatre orchestra (at rear or front of stage) had reed pipes, flute, drums, two gongs, a three stringed-guitar, two-stringed fiddle and cymbals ${ }^{28}$. The appearance of jazz-based syncopation fits well into the texture, without unnaturalness or exaggeration as in Frau Ma's deliberate attempt to destroy Haitang by lying to Ma about her, inventing a betrayal (Scene 4):

\section{Example 3}

The use of fourths and pentatonic writing appears from the start and is a feature of the whole score. Haitang invariably appears to sing 'sehr einfach' (very simply). Here, announcing herself, she is directed to sing

27. A. C. Graham, "The Place of Reason in the Chinese Tradition", R. Dawson (ed.), The Legacy of China, Oxford UP, 1964, p. $29 \mathrm{f}$ and p. $51 \mathrm{f}$.

28. William Stanton, The Chinese Drama, Hong Kong, Kelly and Walsh, 1899, p. 10. 

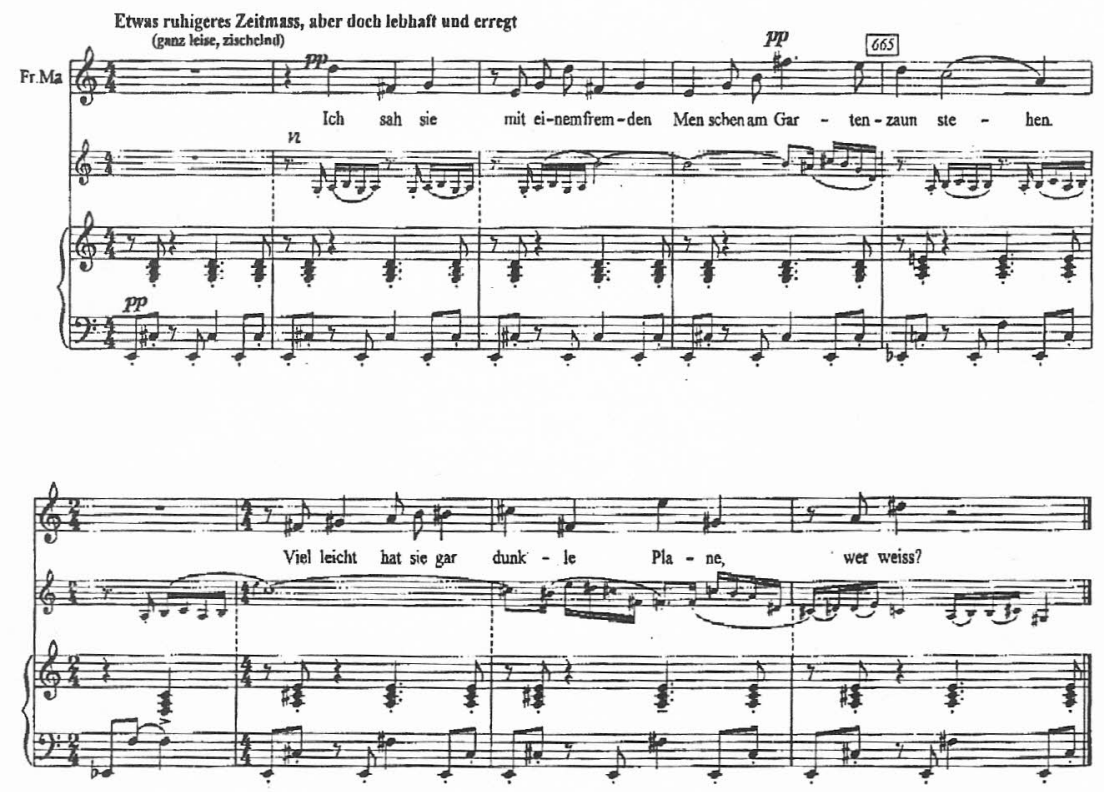

without expression too. That will come later, when she is really challenged:

\section{Example 4}

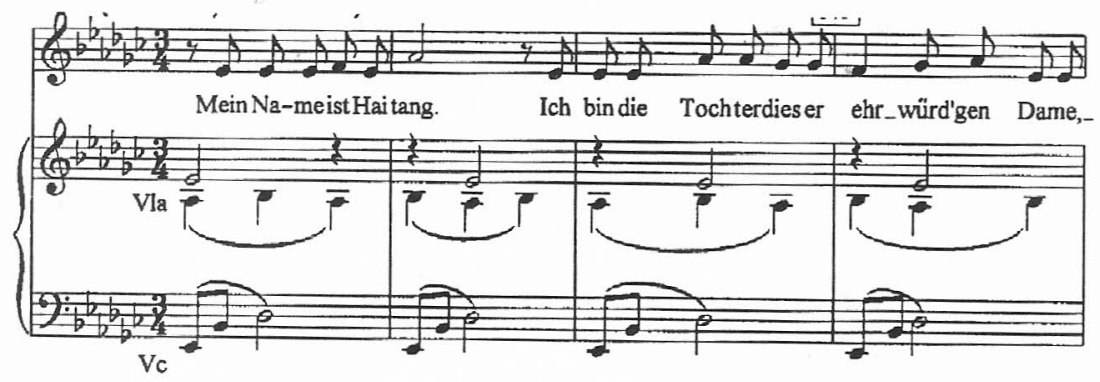


$\mathrm{H}$.
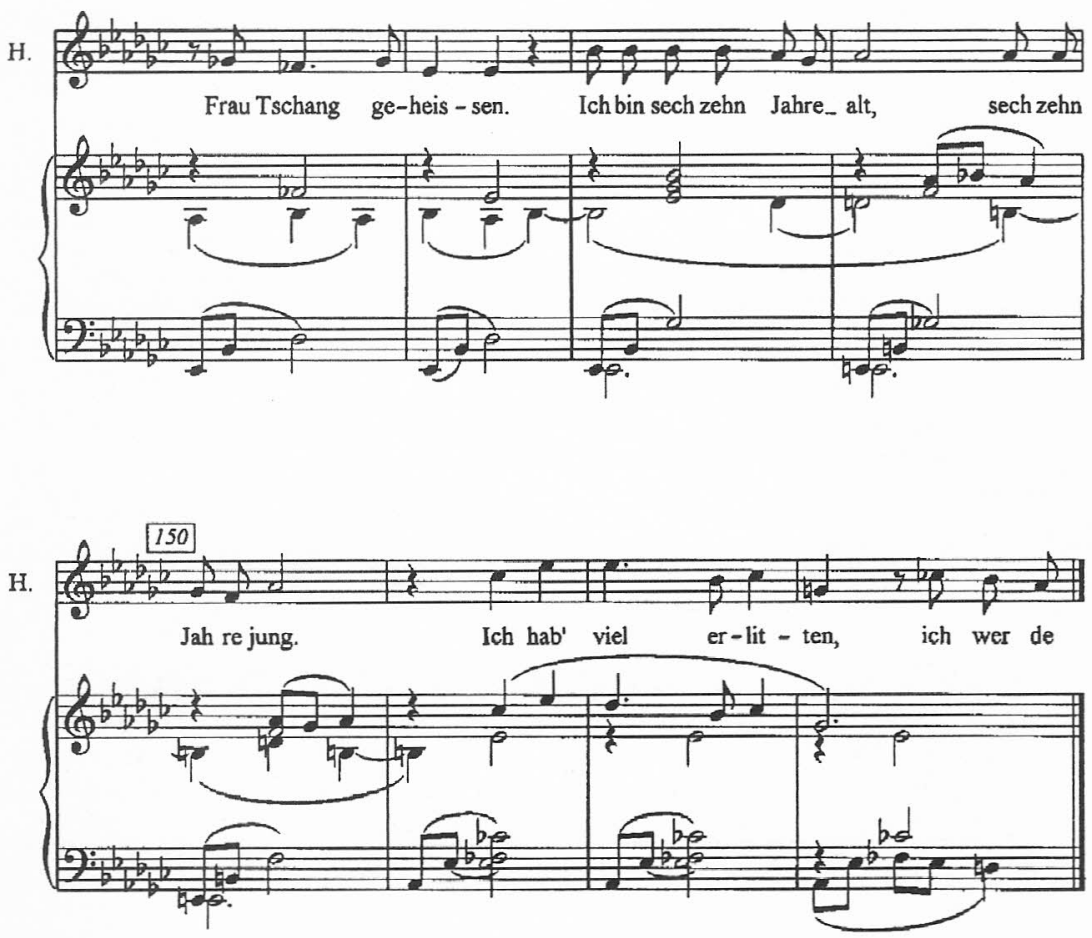

The remarkable, anything but naive Snow Storm Scene (Haitang has earlier given her coat to her brother, and struggles with the bitter cold) begins also with a sustained "fourths" chord on F sharp, B and E, against the jaunty piccolo march tune (in D):

Example 5

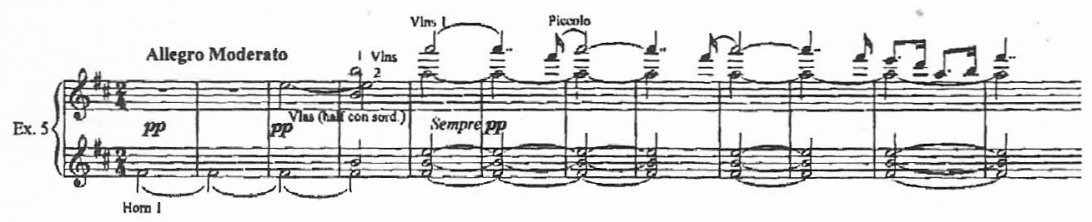

Simplicity again characterises Haitang in her "as soft as possible" song to the Court in Scene 6, after Frau Ma has again lied on her ancestors' bones. Here Haitang's simple words ' $\mathrm{O}$ heavenly light, you have quite disguised yourself. Where are you shining now?' is a reminder of Tamino's 'O ew' ge Nacht, wann wirst du schwinden? Wann wird das Licht meine Augen finden?' in the darkest moment of Mozart's Die 
Zauberflöte. The style here is inflected chromaticism, in the steady $3 / 4$ which fills so much of the score, the accompaniment reminding one that Zemlinsky's song-style in his earlier years seldom advanced into Straussian complexity of texture.

\section{Example 6}
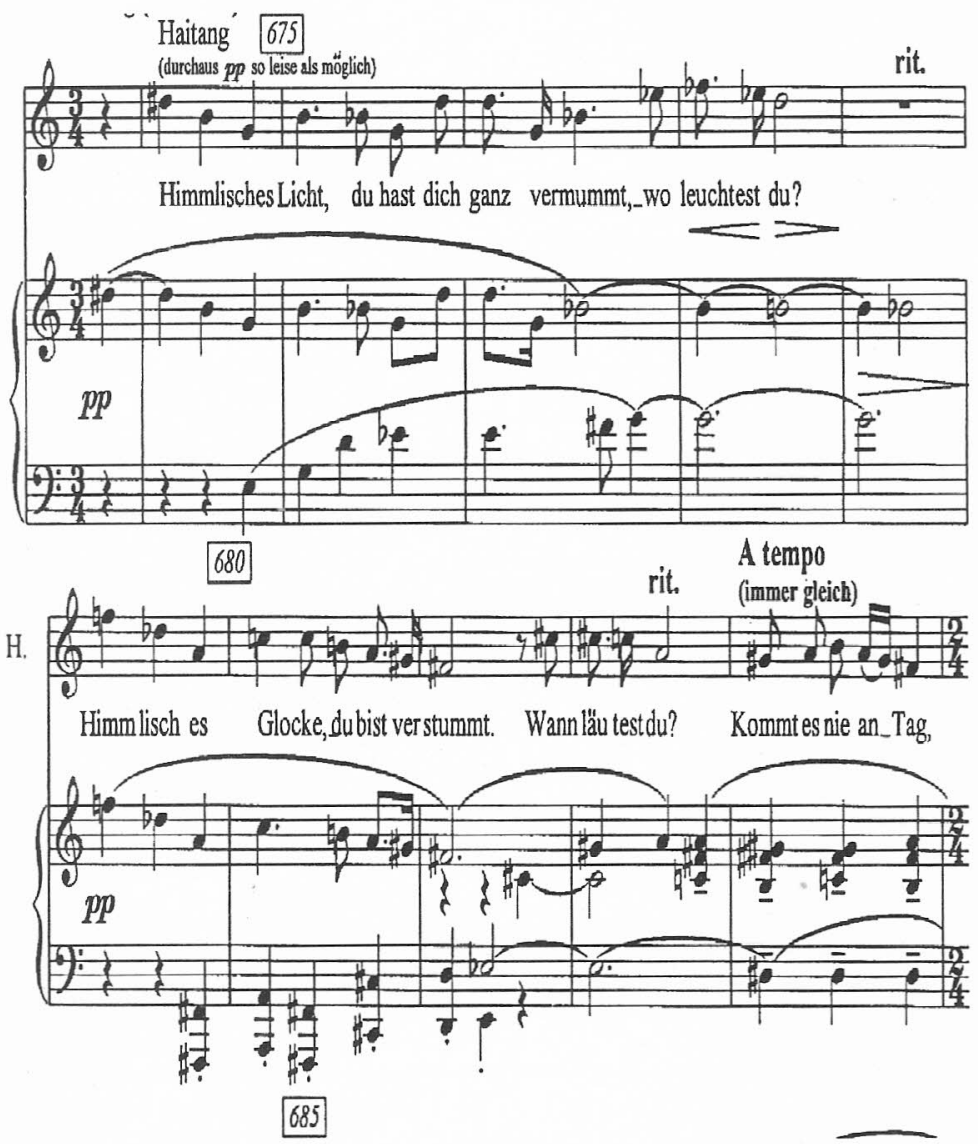

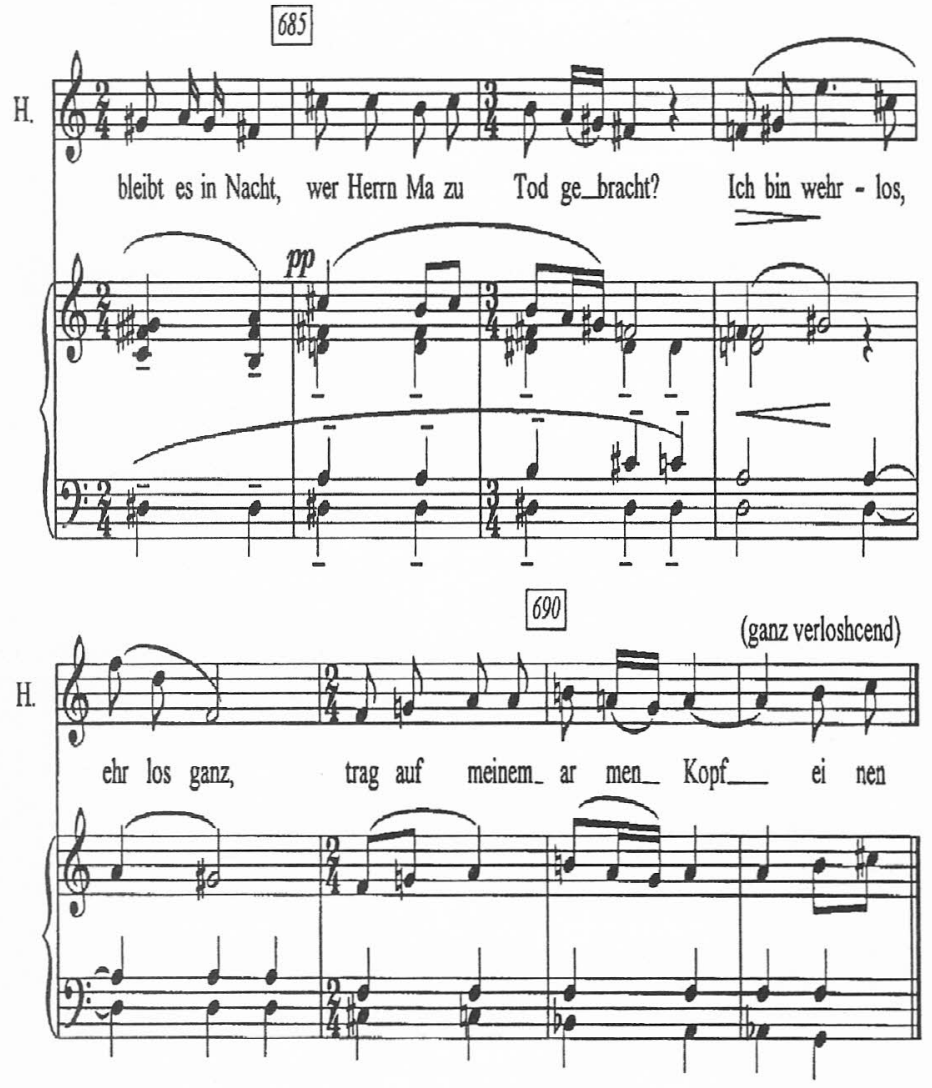

The imagery of light comes later in her very similar song "Tränen der Freude steigen mir in Auge/Am Himmel, die Sonne lächelt wieder" (Scene 4) [Tears of joy fill my eyes: up above, the sun is shining again.]

That stylisation which is the chief characteric of Der Kreidekreis actually works in its favour, though Horst Weber, Zemlinsky's first biographer, was unable to agree with those critics such as Hans Stuckenschmidt, Paul Stefan and Paul A. Pisk, who were thrilled by the work in performance. These were men who were well aware that 
an essential part of this opera/Singspiel ${ }^{29}$ is the Taoist philosophy of acceptance and resignation through inner strength, which gained much ground in post-1918 Germany. The presence of this element is one crucial reason why Der Kreidekreis could never have received official approval in Germany after 1933. 'Rote Abendwolken nach einem düsteren Gewittertag. Es ist das Leben' (Red evening clouds after a gloomy, stormy day. That is life.) sings Haitang after reflecting on the pauper's funeral of her much loved father. She is at the bottom of society fighting upwards. During Zemlinsky's Prague years, the novel Die drei Sprünge des Wang-Lun (the three leaps of Wang Lun) was published (Berlin 1915) continuing a sense of social compassion with another sense of socio-political activism and desire for improvement ${ }^{30}$. Some of this found its way into the novels of Jakob Wassermann. In 1929, a year before Zemlinsky started work on his new opera Döblin published Berlin Alexanderplatz, an extended novel in which the darkness of life among the urban criminal underclass was put under the microscope. In the same period, Franz Schreker, near the close of his opera Christophorus included the words from Lao Tse:

\footnotetext{
Wer seine männliche Kraft erkennt und dennoch in weibliche Schwachheit weilt, der ist das Strombett der Welt. Ist er das Strombett der Welt, so verlässt ihn nicht das ewige Leben, und er kann wieder umkehren und werden wie die Kindlein ${ }^{31}$.
}

Finally, at the centre of the whole drama is the Kreidekreis, the chalk circle which even as it appears becomes ambiguous. Haitang draws the circle on black paper, but turns it from a plain circle (including and excluding) into a wheel by adding spokes. Pao has called

29. Zemlinsky carefully calls it 'an opera in three acts, text (Dichtung) by Klabund' on the title page.

30. See Peter Revers, “Zur Ostasienrezeption in Alexander Zemlinsky's Kreidekreis", Harmut Krone (ed.), Alexander Zemlinsky: Ästhetik, Stil, Umkreis, Wien, Böhlau Verlag, 1995, pp. 78-115.

31. Franz Schreker, Christophorus, oder Die Vision einer Oper, Berlin n. d., Text: Internationale Franz Schreker Gesellschaft, (typescript). 
it the "Symbol der Himmelgewölbes" (the symbol of the heavenly firmament) while for Haitang it is "das Rad des Schicksalwagens" (the wheel of destiny's carriage.) Thus the two traditional functions of the magic circle - as a special protective area and as a symbol of eternity, of the whole (das All) are set forth. The effect of this is not destroyed when it becomes, first a mirror for Haitang (her self-image and self-knowledge) then, grotesquely, a frame for the head of Mandarin Ma.

In the later meeting (Scene 3) between Haitang and her militant brother Tschang-ling, the Chalk motif appears again, drawn with mounting excitement by Haitang as an inconclusive way of foretelling whether Ma, hated by Tschang's Brotherhood of the White Lotus, must die: In this choral progression, Zemlinsky touches on twelve-tone technique:

\section{Example 7}
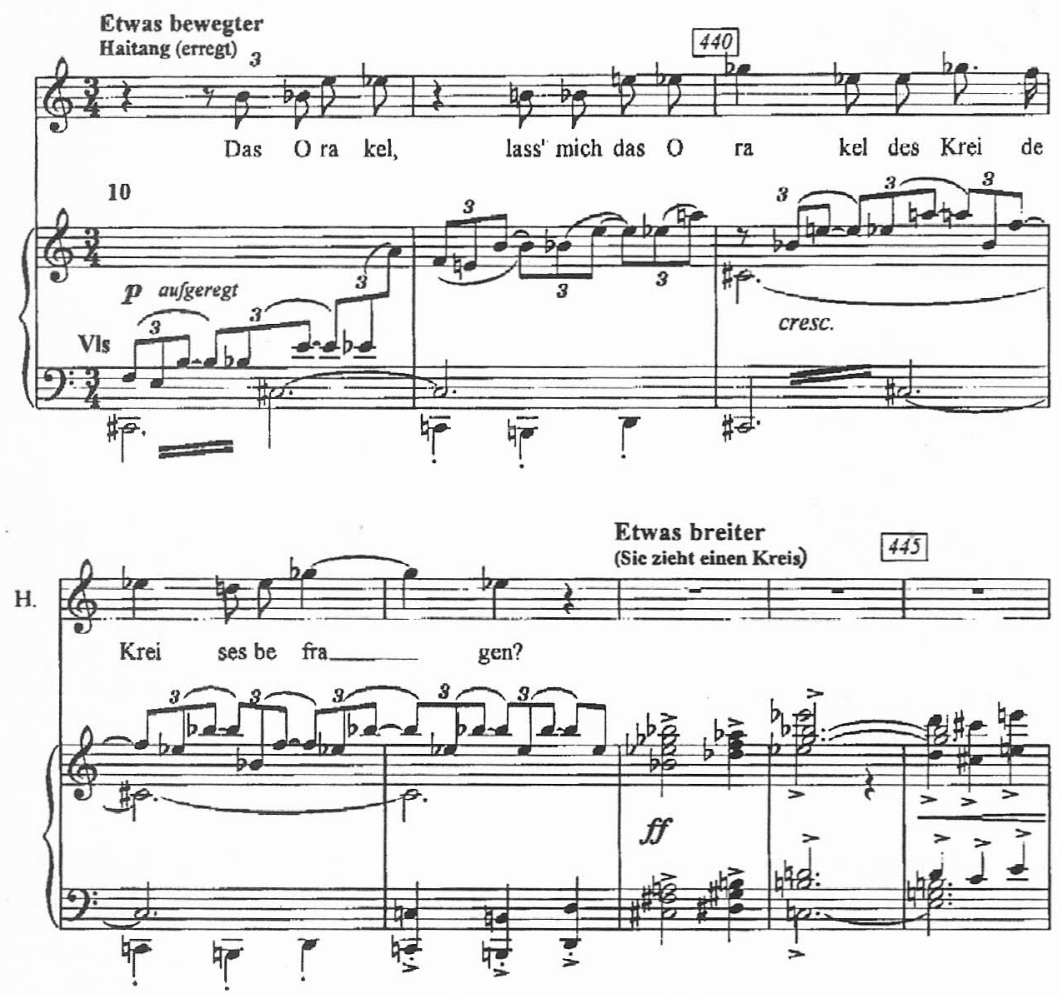
H.

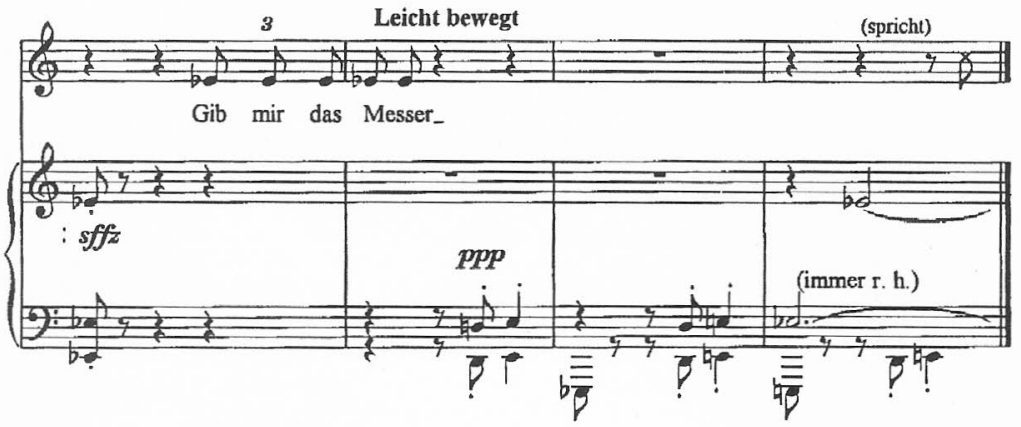

At least the oracle seems to suggest, she herself will not be involved in any act leading to Ma's death. And indeed, on the brink of Ma's end, the realisation of a sort of genuine affection dawns on both $\mathrm{Ma}$ and Haitang, improbable though it may seem. Tschang-ling has earlier (middle of Scene 3) complained of his lot in an almost Wozzeck-like fashion:

Ich hab' keine Heimat, wenn nicht das Feld, Ich hab' kein Haus, wenn nicht das Welt,

Kein Geld, kein liebes Lächeln, das mich nicht hält.

(I have no home but the field,

I have no house but the world,

No money, no blessed smile is mine)

But Haitang, observing all this, wishes to change it. She is ultimately, through her gentle perception, the stronger:

Wie viel Elend ist in der Welt,

Wollen wir nicht versuchen, es zu lindern?

(How much suffering there is in the world,

Shall we not try to relieve it?)[End of Scene 3]

The question of facing up to suffering in the world was a real one for Zemlinsky. Setting Georg C. Klaren's free adaptation of Wilde's Infanta story was one personal response. Creating first the Lyric Symphony, then Der Kreidekreis, through an attraction towards Eastern culture, was another. Zemlinsky's outwardly very successful professional 
life was a battle with geographical restlessness, facing up to personal crises, and with a lack of true public recognition for his composing talents. But his slowly rediscovered works now speak for him in a way not possible in his own time. Among them is Der Kreidekreis, a story artificial yet actual, culturally remote, yet very human - and the work of a master.

\section{List of Music Examples}

Ex. 1 Zemlinsky: 'Schicksalsakkord'or 'Motif of Destiny'

Ex. 2 Motif from Mahler: Symphony No. 9 Andante comodo, opening

Ex. 3 Der Kreidekreis, Scene 4

Frau Ma: jazz-inspired syncopation

Ex. 4 Der Kreidekreis, Scene 1

Haitang's introduction of herself in E flat minor

Ex. 5 Der Kreidekreis, Snow Storm Landscape: Scene 7 opening

Ex. 6 Der Kreidekreis, Scene 6

Haitang: 'Himmlisches Licht' (Heavenly Light)

Ex. 7 Der Kreidekreis, Scene 3

Haitang and the 'Kreidekreis' theme. 